\title{
Beyond Subdivisions: Social History and the Suburbs
}

"After the Sprawl? Suburban Pasts and Futures in the Greater Toronto Area." An Exhibit of the City of Toronto Archives at 255 Spadina Road, Toronto. Running from 27 February, 1998

Sprawling on the fringes of the city/ In geometric order/An insulated border/ In between the bright lights and the far unlit unknown.

Nowhere is the dreamer or the misfit so alone.

- "Subdivisions," by Rush, from the album Signals (1982).

I was sixteen the first time I heard that song. My family had just moved from an older part of town to a spanking new subdivision to the north. I was driving around with my friend Hal Patnaik trying to open other people's automatic garage doors, the suburban version of mailbox baseball. I couldn't understand half the lyrics, but I was sure the song was speaking directly to me. Although I was never much of a dreamer, the misfit line won me over right away, expressing as it did the type of youthful, middle class alienation that, in the late regions of puberty, seemed to pass for genuine suffering.

What is striking to me now is the way the lyrics expressed the dominant cultural assumption that subdivisions weren't really a place, but a space "in between," existing only in relation to other, real places. People did live there, but mostly miserably ("Subdivisions/In the high school halls/In the shopping malls/Conform or be cast out..."); and the song made it clear that the real action was somewhere else ("Drawn like moths we drift into the city/the timeless old attraction..."). Although probably the most explicit, "Subdivisions" was only one of a number of "suburban dude" songs (Mott the Hoople's "All the Young Dudes" through Smashing Pumpkins' "1979") that all made the same basic point: the suburbs might have been the central dream of one generation, but they had quickly become the aimless, placeless nightmare of another.

The youth alienation stuff seems overdone to me now, except as an antidote to nostalgia (those were not the good old days). But I couldn't help thinking of the song as I walked around the inaugural exhibit of the new megaToronto's mega-archives: "After the Sprawl? Suburban Pasts and Futures in the Greater Toronto Area." Using a multi-level text, many colorful photographs 


\section{Left History 5.2}

and maps, and newspaper scrapbooks, curator Michael McMahon, designer Jim Miller and the exhibit team (Vid Ingelevics, photographer; Manda Vranic, researcher and editor; Lewis Nicholson, brochure design; Angela Iozzo, educational outreach and marketing) give us a more intelligent and historical version of Rush's perspective on subdivisions: they sprawl out from the city, seemingly uncontrollably, and represent cultural, aesthetic and environmental hazards to healthy city life.

The exhibit is timely. Metropolitan Toronto has recently endured a forced amalgamation of its five cities and one borough into what was universally derided as "the mega-city." A fairly broad-based opposition to the move emerged across the area, focusing their rhetoric on the un-democratic nature of the initiative. But among many downtowners, there was a barely concealed sense that the move was akin to a forced suburbanization of their idyllic urban streetscapes. Given this local history, understanding the causes and consequences of suburban sprawl seems especially important. But while the exhibit fits into this context, many of the themes parallel developments in other cities.

There is a lot of information in this exhibit, but it is handled very well. The photographs are well presented and colorful and the design has made the main narrative easy to follow. There are several pullout panels that provide more information and nuance on some of the issues raised in the main text. I found myself more drawn to some than others. I suspect that much of the audience will discover the same thing, and will skip some, skim some, and pause on others in more detail. The pullouts are a good way to pitch the exhibit on many different levels of nuance simultaneously without breaking up the main text. This method of presentation shows a sensitivity to the wide range of audiences that public exhibitions should attract-high school students, planners, academics, interested citizens and so on.

The main text traces the twists and turns of Toronto's suburban sprawl from before World War Two to the 1990s. It starts with a 1947 quotation, eerily similar to the perspective of "Subdivisions," from Toronto planning consultant E.G. Faludi.

Acre by acre we are transforming beautiful ravines, fields, parklands, and wooded estates into dismal rows of unsightly identical brick boxes that will be with us for a generation at least. These will be the future slums, growing more and more forlorn as dust from the treeless streets settles on them and the occupants abandon all hope of making attractive anything so basically drab.

The anti-urban sensibilities of experts like Faludi meant that various forms of "suburban dreamscapes" would define the ideal life in the post-war era. These dreamscapes would change as the "reactions to the sprawl of one period begot the sprawl of another," but suburban planners consistently rejected 
what they saw as the unpleasant qualities of urban life: the grid pattern of streets, high density housing, and a mixture of uses-commercial, industrial and residential - in the same area.

In the decade after World War Two, the development at Don Mills in 1954 was most influential challenge to such urban forms. Its private designers planned the development to ensure "the balanced integration of industrial, residential and commercial activities," but separated these uses with greenbelts and roadways. To reject the grid, they laid out the streets in the now familiar suburban curving formation. At its ideal, the exhibit notes, Don Mills represented the best of Garden City tradition. It was to be self-contained (with the majority of residents both living and working there) and surrounded by green belts, farms and river valleys. But the romantic dreams of the designers never worked out. Even worse, Don Mills became an influential model for further growth as acres and acres of countryside were transformed by curving suburban streetscapes. Fred Gardiner, chair of the newly created Metropolitan government, dubbed this growth "multiplication by subdivision."

The 1960s saw increasing concern over this type of suburban sprawl. The "hundreds of square miles of low density development interspersed with expressways, strip development and seemingly random clusters of high rise towers" was more and more "associated with the tensions of big city life." By 1970, Ontario Premier John Robarts announced a plan to contain sprawl on a regional basis. The hope was to establish a parkway belt to break up the continuous urbanization across the Greater Toronto Area (GTA).

Suburban growth in the 1970 s demonstrated that the parkway "did not represent a significant barrier" to continued sprawl. The development at Erin Mills, the exhibit explains, took suburban planning to previously unimagined heights. Houses were planned with "reverse frontages" (facing away from major streets with long walls to insulate them from traffic); main arteries were designed like quasi-expressways; while off the major thoroughfares strangers would be confronted by a monstrous maze of curvy streets. Commercial and residential uses were rigidly separated; even low, medium and high-density residential areas were cut apart by greenbelts and highways. If some planners hoped to limit sprawl, then, it was clear that developers could push multiplication by subdivision to an even greater scale.

In Toronto, it was not until the end of the development boom of the $1980 \mathrm{~s}$ that the tide finally turned against this kind of suburban growth. Land was increasingly seen "as a precious resource that should not be squandered for short term gains." The exhibit has an informative panel on the environmental consequences of sprawl, including a plea to protect the Oak Ridges Morraine. If sprawl disrupts this geological formation north of the GTA, Toronto's river systems could be imperiled.

New development ideas followed from the turn away from sprawl. One major response that the exhibit considers is "the new urbanism." Unlike tradi- 


\section{Left History 5.2}

tional suburban planning, the new urbanism hopes to re-create the jumble of urban space on the fringes of the city by reviving the street grid, mixing residential with other uses and building a variety of densities close together. The exhibit gives the new urbanists their due, but casts a skeptical eye on them as well. While the new urbanism represents an improvement on low-density sprawl, the danger is that it could simply perpetuate "car dependent multiplication by subdivision at higher densities."

The exhibit's creators prefer "our coming to terms with life in the new city and its older suburbs." They celebrate efforts by the former City of Toronto to support the idea of the street as a "richly textured, multipurpose public realm." The hope was "to accommodate some of the regional growth within the area already urbanized." The exhibit ends with some plans developed by the Toronto's Main Streets Advocacy Group, including a case study of "how intensification could occur along a suburban arterial road." Over time, intensification of suburban arterials might develop into "a European-style alternative to further sprawl."

The view of sprawl and the solutions proposed demonstrate the extent to which, in some quarters anyway, the ideas of Jane Jacobs have become a kind of common sense way of thinking about urban development. Jacobs is most famous for the portrait of healthy city life she presented in The Death and Life of Great American Cities (1961), going against what was then conventional planning wisdom to stress the importance of mixed uses, gridded streets and high density housing. But where Jacobs critiqued planning principles by dissecting the anatomy of actual city life, "After the Sprawl?" stays on the level of planning and building. In terms of its historical narrative and the solutions it considers, the exhibit is more about the political economy of sprawl than the nature of life in sprawling communities. Great weight is given to the words of politicians and planners, and to the designs of various developers. But save for a couple of very minor references to neighborhood associations and the requisite dismissal of malls, the exhibit text never really takes up the question of why so many people move into these low density, apparently cultureless places.

The absence of people is particularly striking in the images. The exhibit has a lot of maps and aerial shots, reflecting, both figuratively and literally, a view from the top down. Many of the visuals that actually show people are advertisements produced by subdivision developers, and one suspects that they were used here for ironic or even comedic effect (with fair success: gussied-up models beside models of subdivisions do look rather silly when we know how it all turns out). This view from above does show very well the way sprawl gobbles up huge tracts of land at an admittedly alarming rate, but doesn't do much to confront sprawl as a human creation. The ground-level shots, while technically excellent and very colorful, don't do much better. They are mainly of degraded environments, empty construction sites and lifeless streetscapes: 
half built houses, uninstalled sewer pipes, and street scenes that seem calculated to suggest the kind of bleakness that Faludi found in his "future slums" on the fringe of the 1940s city. The style and perspective of these images remind me of photographic documentaries of rust-belt landscapes, where the point is also tragic: people used to work, laugh, strike and struggle, but the life of the place exists only in memory, and the buildings are merely rusting, rotting shells. Here, however, the rust is replaced by the ubiquitous red clay of the southern Ontario subdivision, and lifeless shells come not at the end of the story, but at the beginning. There is no suggestion that daily human struggles might ever occur there: that people might become attached to their subdivisions, plant trees, add personal touches, make houses into homes and streetscapes into neighborhoods. Here, at least, the subdivision somehow manages to be derelict even before construction.

With the history of ordinary people now near hegemonic in the academy, the image of the social historian riding Paul Revere-like through every museum or lecture hall yelling "the people are missing, the people are missing" should be all too familiar. And so, I offer a bottom-up mea culpa. We all have to choose our topic and our slant, and there is nothing inherently wrong with analysing sprawl from the top down. Focusing on planners, developers and politicians does seem like a quite logical way to communicate a point about (and to) planners, developers and politicians. But the lack of people avoids an awkward question that is buried in the middle of the exhibit, and even then appears only through the proxy of a planner: "do we actually prefer sprawl?" People move "out there" in massive numbers, so we have to consider sprawl as a product not just of the failed romantic dreams of developers and planners, but of the decision-making of a goodly number of suburban dwellers.

Unfortunately, even had they been interested in these sorts of questions, the "After the Sprawl?" team would have had their work cut out for them. Very little writing and thinking on the development of postwar suburbia deals with actual suburbanites, preferring the words of planners, politicians and developers, even when analysing human interaction. Take two well-known examples. Kenneth Jackson's Crabgrass Frontier, the seminal work on the history of suburbanization, bemoans the breakdown of community caused by the rise of what he calls "drive-in culture," but never actually examines how suburbanites interact. Another classic historical work, Robert Fishman's Bourgeois Utopias, stresses throughout the book that suburbia was the collective product of the bourgeoisie, but actual suburbanites are conspicuously absent from its postwar discussion, even while Fishman notes that suburbs have now become remarkably diverse in function. Whether this failure to consider suburban people is a remnant of the arrogant intellectual critique of suburbia that began in the 1950s or simply a product of the ease of finding written records produced by planners and developers is unclear. What is clear, however, is that substituting planners for people, design for actual development, and aerial photos for on-the- 
ground social history produces a rather limited view of the causes and culture of suburbia. We could take a different direction, however, inspired by Joel Garreau's Edge City, and try to grapple with suburbia as the product of human processes.

One of the most interesting, and controversial, features of Edge City is the use of the word "city" in the title. These are places out on the edge, often straddling traditional municipal boundaries, but they are places, and once you call them cities it's pretty hard not to deal with them on those terms. Interestingly enough, Garreau claims in his introduction that he started his exploration believing that suburbia was "morally wrong" and that life "in between" was "insane." He ended up with a more complex view of the motivations of suburbanites. He made this intellectual journey in much the same way Jacobs had rescued cities from modern planning thirty years before: by focusing on the everyday acts of the people who actually live there. Edge City put ordinary suburbanites-commuting, working, and playing —at the core of its story. The really interesting thing about the book, however, is the amount of time it spent contemplating the ideas of planners, politicians and developers as well. The early chapters of the book, which analysed the way edge cities "tick," are remarkable for considering the assumptions and motivations of both developers and suburbanites.

I am no disciple of Garreau, but I would have liked to see "After The Sprawl?" provide this sort of balance. While modern planning, tax policies, the economies of mass production and de-skilled labour processes, and the cultural hegemony of the single family dwelling all favoured a certain type of ultralow density sprawl, the origins and tenacity of suburban form cannot simply be willed away by a critique of planning and design. Yet, we know so little, beyond vague generalizations, about what people were looking for when they moved to the suburbs, or about the kind of attachments they built when they got there. It is about time we left the airborne camera behind and got inside those houses, schools, strip malls and drive-ins to ask the kind of questions that social historians are best at answering. Why did suburban people actually leave the city and what sort of lives did they try to build?

These are not merely academic questions, they go to the heart of any project of re-making sprawl, and point to the exhibit's only major weakness. The lack of people ultimately blunts "After the Sprawl"'s prescriptive message. Much to its credit, the exhibit doesn't merely critique sprawl, but tries to suggest alternative forms of development like the new urbanism and intensifying existing streets. But "After the Sprawl?" is almost completely silent on how we might carry out these plans, noting only that the Main Streets Advocacy Group "recognizes that political leadership will be needed to make main streets intensification work in the interests of inner-block homeowners and street edge landowners, and improve life in the Greater Toronto Area." Considered next to the richness of the exhibit's critique of sprawl, this call for political leadership 
comes off rather flat. Recent urban history tells us that modern planning-in the form of highway building and urban renewal-was blunted in the downtowns of Toronto and other North American cities not just by shifts in planning policy, but by the organizing efforts of a fairly diverse coalition of people. Beginning with quite simple acts, and often embracing quite different means and ends, social activists, community organizers, middle class gentrifiers, and working-class and immigrant neighborhood dwellers managed to save some urban neighborhoods from demolition.

Street-level organizing has also occurred in the suburbs. Newspapers and oral history reveal scattered examples of attempts to control suburban streetscapes, everything from mothers blocking roads to prevent high speed traffic to neighborhoods rallying against the nuisances caused by advertising billboards, hamburger stands and even donut stores. These are the sorts of everyday acts that express deep and meaningful attachments to what so many downtowners consider lifeless sprawl. They are also the sort of acts that could help or hinder attempts to re-make the suburbs. The point is that people become attached to suburban streetscapes just as often as they are repulsed by them, and so to re-make sprawl, we had best start considering the motivations and expectations of suburbanites. Social history, placed alongside the welldeveloped literature on design and planning, seems well placed to start asking these sorts of questions.

The exhibit staff should be congratulated for tackling the political, intellectual and planning history of sprawl so effectively and in remarkably sensible and un-polemical language, especially in a [mega-]city where thinking about urban form is so fraught with difficulty and controversy. But ultimately, their message would have been more successful had they tried to push us past the widely held perspective of Subdivisions: out on the fringes, placeless, faceless sprawl; in the city, the action. I have no desire to see anyone simply invert this perspective, first assuming then celebrating the desirability of suburban culture. Without some sort of figuring out if "we actually prefer sprawl," however, the possibilities of re-making it seem limited.

\section{Steve Penfold}

York University 